\title{
Culture as a dimension of country brand: the highs and lows of Brazil's brand image
}

\section{Cultura como uma dimensão da marca-país: os altos e baixos da imagem de marca do Brasil}

\section{Fabiana Gondim Mariutti}

FEA-RP - Faculdade de Economia, Administração e Contabilidade de Ribeirão Preto, Universidade de São Paulo, Brazil famariutti@usp.br

Mirna de Lima Medeiros

DETUR - Departamento de Turismo, Universidade Estadual de Ponta Grossa, Brazil mlmedeiros@uepg.br

\begin{abstract}
Culturally, a country is recognized internationally as representing a significant aspect of country branding and destination branding. Therefore, the aim of this paper is to explore 'culture' and its associations for Brazil as a country brand dimension, which is the unit of analysis for this interpretive study in England. Thus, after focus group and thematic analyses exploring and interpreting the findings, Brazil was perceived as having a 'diverse and positive culture'. The most surprising finding concerns the participants' awareness of the diversity of associations with Brazil's brand image. Initially, 'football', 'Carnival' and 'Rio' were the prevalent themes of the discussion, followed by 'music'. Brazil's next most recognized unique cultural aspects were 'flipflops', the 'Amazon', 'carnival parades', 'Brazil nuts' and the 'Brazilian native indigenous people'. Nevertheless, Brazil's brand image is, to some extent, more favourable than unfavourable. Thus, this study can orientate strategies for branding campaigns while fomenting business and tourism for a reputable, sustainable and successful country brand.
\end{abstract}

Keywords: Country brand, destination branding, Brazil's brand image, culture.

\section{Resumo}

Culturalmente, um país é reconhecido internacionalmente, representando um aspecto significativo da gestão de marca do país e da gestão de marca do destino. Por isso, o objetivo desse artigo é explorar 'cultura' e suas associações para o Brasil como uma dimensão da marca do país, que é a unidade de análise para esse estudo interpretativo na Inglaterra. Assim, após o grupo focal e análises temáticas, explorando e interpretando os achados, o Brasil foi percebido como possuindo uma 'cultura diversa e positiva'. O achado mais surpreendente refere-se à notoriedade dos participantes da diversidade de associações com a imagem de marca do Brasil. Inicialmente, 'futebol', 'Carnaval' e 'Rio' foram os temas prevalentes da discussão, seguidos de 'música'. Os seguintes aspectos culturais únicos mais reconhecidos do Brasil foram as 'sandálias de dedo', a 'Amazônia', 'desfiles de carnaval', 'castanha-dopará' e os 'povos indígenas nativos brasileiros'. No entanto, a imagem de marca do Brasil é, em certa medida, mais favorável do que desfavorável. Assim, esse estudo pode orientar estratégias para campanhas de gestão de marca enquanto fomenta negócios e turismo para uma marca de país respeitável, sustentável e bem-sucedida.

Palabras-chave: Marca do país, marca de destino, imagem de marca do Brasil, cultura.

\section{Introduction}

Culture is a significant dimension of country brand and plays a key role in country branding and in destination branding. The theories in the field provide useful descriptions regarding the multidimensionality and complexity of a country brand due to the number and variety of stakeholders involved (Anholt, 2007; Florek \& Insch, 2008; Dinnie, 2009, 2016; Fetscherin, 2010). For Dinnie (2016, p.5), nation brand is "the unique, multidimensional blend of elements that provide the nation with culturally grounded differentiation and relevance for all of its audiences".

Furthermore, the literature in the field confirms the cultural dimension of country brand image (Anholt, 2007; Anholt \& Govers, 2014; Buhmann \& Ingenhoff, 2013; Dinnie, 2009, 2016; Florek \& Insch, 2008; Mariutti \& Silverio, 2016; Rojas-Méndez, 2013). Following Kotler, Haider and Rein's (1993, p. 141), the comprehensive concept of country image - from a branding perspective - is "The sum of beliefs and impressions people hold about places. Images represent a simplification of a large number of associations and pieces of information connected with a place". Additionally, place image has been intensely studied since the 1970s after applying marketing, branding, and management principles and practices.
Before proceeding further, it is necessary to clarify that 'country' brand and 'nation' brand are used interchangeably throughout this paper. In addition, it is necessary to clarify that culture, as a country brand dimension, includes several aspects, such as art, music, dance, folk, film, history, nature, architecture and sports. Kotler and Keller (2002, p.251) stated that a "country's image results from art and music" among other aspects. As suggested by Castro and Giraldi (2012), elements of Brazilian art, history and architecture should be explored in greater depth for Brazil to be recognized for these aspects. Brazil has an enormous number of rhythms and traditions that are known worldwide; these are due not only to its size but also to the way ethnic groups have merged to form its people (Ribeiro, 1995).

In view of this context, the aim of this paper is to explore 'culture' and its associations as a country brand dimension, using Brazil as the country for this analysis through a small-scale study of English people. The paper begins by briefly discussing the theoretical foundations in the literature and the contextual status of Brazil. Then, the methodology is presented regarding the focus group approach to explore Brazil's brand image and its associations. Next, the findings and analysis are discussed, followed by the final remarks. 


\section{Literature}

\subsection{Place Branding \& Destination Branding}

Place branding and destination branding are related fields of knowledge, as shared purposes and efforts can be aligned for enhancing a city, a region or a country image from a place branding perceptive. While authors in place branding agree that place image is a result of the place identity focused on several aspects of the place by creating, monitoring and promoting the place via communication channels, authors in destination branding focus on the touristic scheme of the attractive attributes, tourism-related products and services along with the geographical landscapes and landmarks. However, both involve perceptions of places. From a destination branding perspective, "The image of a place is an important aspect as it involves the tourists' perceptions of places" (Carniello \& Santaella, 2013, p.293). A tourist begins to formulate a destination image before the decision to visit the destination is made, but this image can change (more or less significantly) before travelling, while travelling, as well as after their return (with effects on the level of tourist satisfaction, loyalty and the likelihood of recommending the destination), according to Martín-Santana, Beerli-Palacio \& Nazzareno (2017).

Destination branding as a field has been related to destination marketing, concerning the development of tourism brands (Pike 2008). In addition, Hall (2010) agrees that there have been many studies of destinations regarding country image in order to elicit attributes associated with specific places. For Szondi (2007, p.13), "As far as the evolution of place branding is concerned, destination branding precedes country branding, which requires a more holistic and creative approach". According to O'Neil (2007, p.9), destination image has been researched since the early 1970s using case studies. Moreover, tourism industry professionals and research specialists are continually enlightened in their own studies as well (Ashworth \& Kavaratzis, 2010; Moilanen \& Rainisto, 2009; Pharr, 2005; Pike, 2008). Additionally, Szondi (2007, p.12) discusses that "While the organisation behind destination branding is clearly identifiable and visible (national tourism organisations or tourist boards), the situation is more complicated in the case of country branding" because there are several stakeholders and multiple dimensions of a country brand.

For Kavaratzis (2005), the application of marketing efforts was initially developed for place promotion, then place marketing and, ultimately, place branding based on two distinct trends: place marketing theory and the practices started by city administrators. According to Medway and Warnaby (2009), place branding draws not only on classical branding theory, but also from the areas of relationship marketing, services marketing, tourism marketing, and urban planning, in order to understand the branding concept in this specific context.

In addition, "Place branding has been defined as the practice of applying brand strategy and other marketing techniques and disciplines to the economic, social, political and cultural development of cities, regions and countries" (Bellini, Loffredo, \&
Pasquinelli, 2010, p.90). Likewise, according to Maheshwari, Vandewalle and Bamber (2011), place branding plays an important role in the sustainable development of a place, which leads to the promotion of the place and thereby creates stronger place brands. Both references orientated the overall aim of this paper, which explores culture in order to enhance the reputable, sustainable and successful country brand.

According to Pike (2008), from a destination branding standpoint, national stereotypes can permeate the perception of a brand. The same can be said about country branding. As understood by Dinnie (2016), the influence of a country brand image first inheres in personal experiences (working or holidaying); moreover, there are several other sources of country brand e.g., word of mouth, pre-existing stereotypes, political events, citizens, brands from the country, national sporting teams, films, and media. In line with that, the management of country reputation should be emphasized and continuously administered by the main internal stakeholders of the country (e.g., the government and citizens).

It is known that a country brand echoes its image abroad (Anholt, 2007; Dinnie, 2009, 2016; Olins, 1999), whether using country branding strategies or not, for example, by simply performing its role worldwide, economically, releasing a film, winning a sports competition, attracting international students, promoting destinations online, creating jobs, producing science, or participating in United Nations summits. Therefore, either destination branding or place branding strategies can support these aspects to improve the reputation of a country, by identifying issues likely to threaten country brand success. By doing so, articulating a value proposition for a country functions as an indispensable bridge between citizens and investors, government, and local community and business aspirations - for adding value in countries, regions and cities. However, tourism or any other sector may or may not contribute to improving or damaging the image of a location; "it is possible to work on the image by avoiding negative distortions and focusing interest on cultural economic and social benefits" (Carniello \& Santanella, 2013, p.293).

A country branding strategy that supports exports specifically may also promote better public diplomatic relations between countries or reinforce the tourist sector. On the other hand, using destination branding strategies may also support international business or foster educational partnerships. For example, if the tourism industry advances, it certainly also increases the nation's sustainable development. An important final example is that, in order to attract talented researchers, the country can also increase internal investments and vice versa.

By summarizing the previous conceptual debate, it can be said that country branding strategies are represented by branding strategies and communications channels that originated in marketing communications grounded in the country brand construct (identity and image). From the marketing perspective, the concept of country brand image, which is the qualities and associations that the market associates with a specific brand, is 
expressed through situational choices and noteworthy preferences for brands that are reputable, sustainable and successful. This first section of this paper conceptually supports the aim of this paper as the robust theoretical linkage between both fields of knowledge - place branding and destination branding.

\subsection{Brazil as a Unit of Analysis}

There is a lack of research about Brazil's brand image conducted in England. Nevertheless, international business and tourism between both the countries are potentially promising, greatly necessary and continuously increasing each year. For instance, the United Kingdom Trade and Investment's (UKTI, 2016) mission with Brazil is encouraging; "We develop and sustain the important and longstanding relationship between the UK and Brazil. We work on a wide range of political, commercial, security, defence, and economic matters of interest to the UK and Brazil, and provide consular support to the many Britons visiting and living in Brazil". According to APEX-Brasil (2016), which is the Brazilian Trade and Investment Promotion Agency, the commercial opportunities for Brazilian products in the United Kingdom are food, agribusiness and beverages, home and construction, machines and equipment, fashion and multiple other sectors.

From the tourism sector context, England does not represent a top destination according to statistics from Embratur (2016), yet it is among the top ten countries that sends visitors to Brazil annually, and the number of tourists is really growing each decade. For instance, 38,532 English tourists came to Brazil in 1995, while 169,514 came in 2005. In 2015, the number grew but not as in the previous decade with 189,269 English tourists travelling to Brazil (Embratur, 2016).

Previous studies confirm the need for studies on Brazil's brand image, which is viewed with various positive and negative associations internationally (Anholt, 2007; Bignami, 2002; Giraldi, Giraldi \& Scaduto, 2011; Kotler \& Keller, 2006; Mariutti \& Giraldi, 2013). Furthermore, a country brand image is a multidimensional construct and a complex theoretical archetype; it represents a combination of brand associations and is perceived by various stakeholders. In summary, the image of a particular country can be understood as the set of present and strong associations between the country and any other information in the stakeholders' memory, experiences, or awareness. Moreover, a place (e.g., a region, city or country) may attract media attention due to cultural events (Caldwell \& Freire, 2004, p.57).

Over the last decade, the number of studies about Brazil's brand image has increased, positioning the country as a potentially researchable area with boundless theoretical and methodological opportunities in the academic world. For instance, Dinnie (2009) notes that the cultural dimension should be taken into consideration when focusing on country brand image research in an overall dimensionality approach. Mariutti and Giraldi (2013, p.13) concluded in their research focused on
Brazil based on the Anholt Nation Brand Index that culture as a dimension received the lowest score among four countries (Japan, China, the USA and the UK). After calculating the score of the six dimensions attributed to Brazil considered by the Anholt Index, the sequential order (with a maximum possible score of 50) was as follows: products (27), government, (23), people (21), immigration and investment (20), tourism (18), and culture (17). The study suggests that Brazil's brand image needs to be enhanced through the construction of its brand and communication in the international market in order to improve its exposure by promoting its culture and attracting tourists. Authors agree that Brazil's culture plays a role on the country exhibition internationally.

For Rohter (2012), Brazil represents "remarkable artistic output" (p.283). In this vein, O'Neil (2007) notes that the preference for Brazilian popular culture been value-added, as the travel and tourism sector has also increased, but she adds that "it is also the case that Brazil has a reputation for insecurity due to gun crime and high crime levels relating to muggings against tourists" (p.21). Brazil's negative aspects are clearly known worldwide, such as crime, violence, drug dealers and the high level of poverty (Anholt, 2007; Bignami, 2002; Kotler \& Gertner, 2004; Mariutti \& Giraldi, 2013).

Regarding one study on nation brand personality, Kim, Shim, and Dinnie (2013) investigated the dimensions of nine countries regarding country branding. Accordingly, Brazil was classified as a "country for investment" (p.40), and its highest dimension for brand personality was "excitement", followed by leadership, peacefulness, tradition and sophistication (p.46). The conclusion of their findings was that "excitement" was important to countries' desirability as tourist destinations; therefore, Brazilian policymakers and country branding professionals should direct their planning to the relevant personality dimensions, both previously mentioned. Nevertheless, culture was not measured in the study.

However, from a destination branding perspective, Brazil has a strong and positive image and expectations are for the most part met or exceeded for British travellers, for instance, regarding the tourism sector - according to O'Neil's study (2007). Her research (2007, p.20) concludes that Brazil's country reputation actually seems to be exaggerated concerning negative associations, as its "reputation seems to be worse than the reality that tourists experience". Specifically, concerning British travellers as a sample, O'Neil's (2007) quantitative research has reported that Brazil has a strong national identity because of its vibrant culture, variety of people and natural beauty, which definitely translate into a positive tourist image. However, she concludes that "In order to increase British travel to Brazil, the salient and positive image aspect must be cemented in the minds of the British through induced marketing efforts. To increase the variety of destinations visited; fuller information on the quality of its tourism infrastructure should be provided" (O'Neil, 2007, p.22). 
Another approach to exploring country brands is through country brand indexes, which are real-data based on proficient corporate and consultancy initiatives. Since 2000, several indexes have been attracting a great deal of interest. These country brand indexes provide significant and accurate insights into the country brand topic with regard to investigations based on their own core dimensions and the current globalized world (Mariutti \& Tench, 2016) A country's singularities are not considered; despite their status quo and economic condition - whether developed or developing country - countries are positioned in the overall ranking. Mariutti and Tench (2016) have contributed to the expansion of this topic by exploring Brazil's position in several indexes, such as the Country RepTrak (2015), the Digital Country Index (2015), Fetscherin (2010), the East-West Nation Brand Perception Indexes and Reports (2011), the Good Country (2016), the Global Peace Index (2015), and the FutureBrand Country Brand Index (2015). Henceforward, rethinking these indexes could "contribute to the field by providing texture and integrity to country brand considerations in both the current and future framework of the expanding international economy, the advancement of global marketing, diplomatic relations, academic interchanges, and national sustainability itself" (Mariutti \& Tench, 2016, p.58).

To close this theoretical and contextual debate, this paper proposed a new analysis of Brazil's brand to explore how culture (and its associations) constitutes as a country brand dimension. As stated by O'Neil (2007, p.21), “Brazil must ensure its global image is positioned consistently with the various products it promotes". Furthermore, by analysing the country brand image and associations, the country gains information for developing strategies and tactics for undertaking place branding and destination branding.

\section{Methodology}

\subsection{Focus Group Approach}

The methodology of this research was carried out using a qualitative approach with a focus group to obtain the primary data. A "focus group is not a group interview, it is a group of people gathered together to discuss a focused issue of concern" (Liamputtong, 2011, p.31). Historically, the use of focus groups, which is a special qualitative research technique, has grown quickly in the last twenty years (Neuman, 2014) and is used especially in marketing and media research (Flick, 2014) and has been adopted by social researchers since 1943 (Liamputtong (2011). "Originally, the participants were asked to push buttons to indicate their responses, positively or negatively, to the radio programs", reminds Liamputtong (2011, p.9).

For Flick (2014), a problem with the confidentiality of focus groups is how to document the data regarding the participants' identifications; therefore, a focus group's consent form was developed and signed by the participants as recommended by Liamputtong (2011), Creswell (2014), and Flick (2014).
For group compositions, the purpose was to invite potential participants interested in the topic to derive a homogeneous group in terms of its preferences about Brazil (Flick, 2014; Liamputtong, 2011), which is called "natural group" by Flick (2014, p.245). A focus group enables in-depth discussions focused on this specific area of interest (Flick, 2014; Liamputtong, 2011). Consequently, a focus group was used to provide rich and detailed information about the feelings, thoughts, impressions, and perceptions about Brazil from the people in their own words (Liamputtong, 2011). This was conducted using purposive sample (Creswell, 2014, p.155), which is normally adopted in focus group research (Liamputtong, 2011, p.50). For this non-probabilistic sampling (Neuman, 2014), first, three types of invitations were adopted to invite participants from my network: email messages, social media posts, and printed posters in September 2015. The poster layout was designed as a channel of communication for inviting people to participate as invitations through printed posters, which were fixed bulletin boards in four buildings at the City Campus and five buildings at the Main Campus of the University in Leeds. Liamputtong (2011) also suggests this recruitment technique.

Appropriately, the focus group is a key research approach for interpretive enquiries, where "the researcher can see directly how the participants take part in discussion, share ideas, views and experiences", leading to the socially constructed interaction experience (Liamputtong, 2011, p.17). Moreover, Zenker et al. (2013) suggest focus group interviews as one method to evaluate city perceptions, which can be extended to a country setting as well. A focus group involves a small-sized interview group of five to eight participants who discuss a specific topic together for 30 to 50 minutes (Flick, 1997). However, Neuman (2014) suggests six to twelve participants, while Liamputtong (2011) recommends between four and ten participants; Creswell (2014) suggests six to eight.

An original focus group protocol was created with a heading (date and place), instructions followed by the topics, a listing of the parts of the discussion, icebreaker questions and concluding statements, probes, a 'thank-you' declaration (Creswell, 2014) and a space for notes. For instance, the probe and prompt questions were implemented to discuss an issue further to obtain a clearer understanding of and inferences from the discussion, and other types of questions were also used, such as follow-up, specifying, direct, and indirect questions (Liamputtong, 2011). Therefore, by comprising original topic discussions and creative and projective techniques, the protocol of the focus group was defined. As a result, three parts of the group discussion were established for the main overarching topic 'How do people in the UK perceive Brazil's brand image?'

- PART I-Discussing their awareness of Brazil's brand image

- PART II - Recognising associations with the overall image of Brazil

- PART III - Mentioning positive and negative associations with Brazil 
Next, the structural content of each part is presented, followed by the findings and analysis to determine the applicable and logical interpretations.

\section{Findings and Analysis}

Five English participants participated in this focus group on October $23^{\text {rd }}, 2015$, from 4 to $4: 43 p m$ on Sunday in the city of Leeds, England. Their names have been kept anonymous for confidentiality reasons, and their profiles are described below:

[K] is a journalist and owns a radio programme.

[W] is a university lecturer in economics.

[X] is a lecturer and holds a PhD in astronomy.

[Y] is an administrator and attends Brazilian Portuguese classes.

[Z] is the only participant who has been to Brazil, speaks a little Brazilian Portuguese, and works for a charity.

Five participants are an acceptable number for a focus group (Liamputtong, 2011), and despite this small number of participants in this sample, the subjective data were substantial in terms of the qualitative evidence and thought-provoking findings about Brazil's reputation.

Methodologically, focus group data are appropriate for a thematic analysis, which is also compatible with various theoretical conceptualisations (Flick, 2014). Furthermore, thematic analysis was used to analyse the focus group when exploring the themes that emerged from the data, as suggested by Liamputtong (2011). Therefore, in order to ensure the development of specific themes and to explore the participants' own perceptions regarding the associations and dimensions of the country brand, where a variety of perspectives were expressed in the three parts of the focus group, the group discussion findings are developed by analysing the content and the interactions among the participants of the discussion (Liamputtong, 2011). As part of the procedure adopted for the current transcription criteria, based on Liamputtong (2011, p.167), the following symbols and instructions for reporting the data from focus groups were used:

- (...) means pauses

- (Overlapping) means a participant interrupts the talk

- CAPITAL letTERS indicate emphasis

The Bem Brasil restaurant in Leeds, England, was the chosen place for hosting the focus group, where people could informally be 'interviewed' in a group discussion setting and freely express their ideas and opinions (Neuman, 2014). It is also located in the city centre, near the City Campus of the university. Moreover, there is a separate room on the first floor for reserved meetings - offering "a private, quiet, comfortable, large space free of distractions" (Liamputtong, 2011, p.57) and providing a relaxing environment for the participants as well (Hair, Wolfinbarger, Ortinau, \& Bush, 2010). Afterwards, the participants enjoyed refreshments and Brazilian snacks provided by me as a form of gratitude and a brief get-together as well since there was no incentive to participate beforehand (Liamputtong, 2011). Each participant received a 'thank you' card with a small Brazilian flag attached to it. The refreshments prepared by the restaurant included the following Brazilian foods: coxinha (made of chicken), croquete (made of beef), typical cheese bread, and fresh juices (mango and passion fruit).

In summary, considering the practicalities of conducting the focus group (Liamputtong, 2011), agreements, rather than disagreements, were mostly seen in the group context, as reported above - indicating the strength of the perspectives held by the participants. In addition, the focus group context was held in an authentic and friendly environment with no difficult situations, dominant talkers or hostile individuals (Liamputtong, 2011).

After the transcription of the participants' discussion (Flick, 2014), the data were analysed using a thematic analysis. Methodologically, data coming from the focus group are appropriate for thematic analysis, which is also compatible with various "theoretical conceptualizations" (Flick, 2014, p.423). Next, the structure of the group discussion is presented followed by the findings and analysis of the three parts.

\section{Part I-Discussing their awareness of Brazil's brand image}

During Part I of the focus group, there was an in-depth discussion to ensure that specific themes emerged and to explore the participants' own perceptions regarding the 'culture' dimension. It began with a discussion of the participants' awareness of Brazil's brand image. As stated by Liamputtong (2011, p.5), the focus group is useful in exploring and examining what people think regarding "how they think and why they think the way they do about the issues of importance to them without pressuring them into making decisions or reaching a consensus."

Overall, most of the participants confirmed that the strongest associations with Brazil are 'football', followed by 'Carnival' and 'Rio'. [W] said "Definitely FOOTBALL. It is huge in Brazil. It was the best team ever".

Several Brazilian 'films' were also covered in the discussion. While a minority of the participants mentioned images such as 'hot weather', 'favelas', and 'Amazon' - they all agreed that 'music' is strongly associated with the Brazilian culture. $[\mathrm{Y}]$ commented on the diverse culture; moreover, [K] said, it is a "positive culture". [X] mentioned "jazz, food and drinks" as well. Regarding 'music', [Z] mentioned bossa nova and samba, adding the ideas of "Open street parties and sports and tiny bikinis (body-image)".

Next, the participants were asked to list the top three images of Brazil that come to their mind as associations of the country. The replies are transcribed and described below:

[K] "Football, Rio, Carnival and hot weather"

[Y] "Carnival, football and favelas"

[W] "Of course, football, the economy, and beautiful woman"

[X] "Football, the Amazon, and Christ the Redeemer" 
[Z] "Music (bossa nova and samba), open street parties, sports and tiny bikinis (body image)"

Later, [Z] added "Ah, bossa nova. Samba as well. I can see people PLAYING FOOTBALL AT THE BEACHES...in the STREETS, EVERYWHERE. I THINK OF PEOPLE BEING OUTSIDE, IN THE STREETS".

Interestingly, only one participant [X] brought up the 'Christ the Redeemer' statue in Rio de Janeiro. Although, it is greatly promoted as one of the most visited cities in Brazil. 'Rio de Janeiro' was repeatedly the source of queries by most of the participants, as [K] probed "how come it is not the capital of the country? I have never heard of Brasilia. WHAT IS SPECIAL IN BRASÍLIA?" This led to a discussion about the changes in capitals of Brazil. Regarding food and drinks, Brazilian barbecue, called, 'rodizio' and 'caipirinha', was recalled by most of the participants.

A recurring theme in Part I of the discussion was a sense amongst the participants that 'crime' is associated with the country, whether in film plots, at the beach, in politics, or on the streets. Some felt uncomfortable talking about it while others considered 'crime' and 'violence' to be associated with the country. One participant expressed the belief that Brazil has no safety, as [Y] observed "When I say to people that I want to visit Brazil, people tell me it is dangerous."

During the discussion, one participant $[\mathrm{Y}]$ also commented a negative association with Brazil: "Another association with Brazil is prostitution. I once read about the prostitution near the stadium built in the northeast... before the World Cup".

Kajihara's (2010) analysis of the images of Brazil that were disseminated abroad through promotion materials produced by the Brazilian Institute of Tourism - EMBRATUR (which is the official state-owned agency for Brazil's promotion abroad), may explain these results. She showed that the promotional efforts of the agency over many years focused on stereotypes of Brazil, such as Rio de Janeiro (with its icons: Christ Redeemer and Sugar Loaf), carnival, football and sensualized women (e.g., wearing bikinis or at the carnival). EMBRATUR's work in the decades from 1970-90 consolidated a Brazilian image linked to the erotic and exotic (Gomes, 2012).

It was just in the beginning of the current century (around 2002) that the promotional focus changed to the country's cultural and natural diversity because of the perceived negative consequences of those stereotypes, such as sexual tourism, prostitution, and the mistreatment of Brazilian women abroad (Kajihara, 2010), and due to social movements against the objectification of woman (Gomes, 2012). Kajihara (2010) emphasizes that the current promotional plan uses different kinds of attractions and can appeal to multiple audiences, but it takes time to reposition the country's image abroad. Gomes (2012) also states that it is a rebuilding process, which aims to connect the Brazilian image to heritage richness, modernity and "brazility" that is complex and takes a longer time.
This new approach aligns with the World Commission on Culture and Development, according to which "cultural diversity is not simply an asset to be preserved but a resource to be promoted" (UNESCO, 2009, p. 3). Although the agency's efforts seem to seek a cultural commerce, it is important to notice that this commerce is "[...] a two-way process that takes place in an increasingly complex and interactive international context" (UNESCO, 2009, p.14). Furthermore,

Concerning communication and cultural content, the focus is on the importance of overcoming certain obstacles that, by hampering the free circulation of ideas by word and image, can impair our responses to cultural diversity. Persistent stereotypes and major disparities in the capacity to produce cultural contents are a particular concern and call for greater efforts to promote media literacy and information skills, particularly through the information and communication technologies (ICTs). (UNESCO, 2009, p.6)

The material produced (the promoted image) by official public agents or by the members of the trade are not the only influences on the public's awareness about Brazil's country brand image. We discussed some of the influences in the "Place Branding \& Destination Branding" section of this paper. One of these influences is the information spread through the news. Therefore, it was a topic of discussion in the focus group.

When asked to tell me about the repercussion of the Olympics in the UK, the majority of the participants reported that not much about it had been published at the time, as the refugee crisis was mostly in the news. Interestingly, they brought up the news which they were going to be requested to discuss next- to talk about the news' role on the formation of a country brand image and if the news influenced them. All of them shared the opinion that the news influences their image of the country. However, two of them were more careful. As [W] said, "Yes, news influences me partially. But, it has to do with the source as well". As [Z] put it, "It depends on what I already know about the country. Does it influence what I do not know about the country, generally yes".

Moreover, the original transcriptions are presented next.

[Z] mentioned that "Radio 3 (BBC News) showed many documentaries about Brazil before the World Cup in 2014".

Researcher: (overlapping) Does anyone else share this opinion as well?

[Y] said "Palin has done several documentaries in many places in Brazil".

[W] remembered the documentaries as well, especially during the World Cup in 2014.

Three of the participants remembered documentaries on TV and on the radio about Brazil. One participant $[\mathrm{Y}]$ said "Palin has done several documentaries in many places in Brazil". Two participants reported that the documentaries were broadcasted during the World Cup in 2014. 
Taken together, these explorations suggest that there is an association between 'culture' and a country brand image, which was discussed in the literature review by most of the authors.

Part II - Recognising associations with the overall image of Brazil

For the Part II of the focus group, top international Brazilian brands and Brazilian products, followed by Brazilian tourist destinations and typical Brazilian cultural photos were visually prearranged and displayed. Photographs are increasingly recognized as genuine forms and sources of secondary data and are accepted as an instrument and object of research (Creswell, 2014, p.335). Thus, these photographs suggested visual representations of Brazil's brand associations for the participants' experiences as well. Furthermore, this procedure for data collection follows Hair et al. (2010, p.119), using projective techniques for indirect enquiries through photograph tests in order for participants' perceptions to provide beliefs and feeling about the country brand associations. One disadvantage of this technique relates to the complexity of the interpretation, according to Hair et al. (2010, p.119).

Therefore, sixteen photographs were carefully selected for the projective technique in order to enrich the other methods in this methodology and as a way of using data originally not produced for research purposes for contribution in the field as well (Creswell, 2014, p.302).

Thus, the participants were asked to recognize and rate these photographs related to Brazil's brand image. The percentages and ratings analysis were gathered from a web survey platform using Squarevey, which offered a digital type of interaction (touch screen) and quantitative approach during the focus group method developed for this projective technique. Using a Likert scale as a graphic rating scale (Hair et al., 2010, p.185), "people indicate a rating by checking a point on a line that runs from one extreme to another" (Neuman, 2014, p.230) for the mostly known or less known associations to Brazil. Moreover, Flick (2014, p.528) states that using visual and electronic data is "important in the collection of qualitative research beyond traditional forms of interviews, focus groups or participant observations".

Furthermore, this procedure for data collection follows Hair et al. (2010) for using projective techniques for indirect enquiries through photograph tests for the participants to provide beliefs and feeling about the associations with the country. Figures 1 and 2 below are illustrated by the screenshots.

Figure 1 - Photos for the Projective Techniques

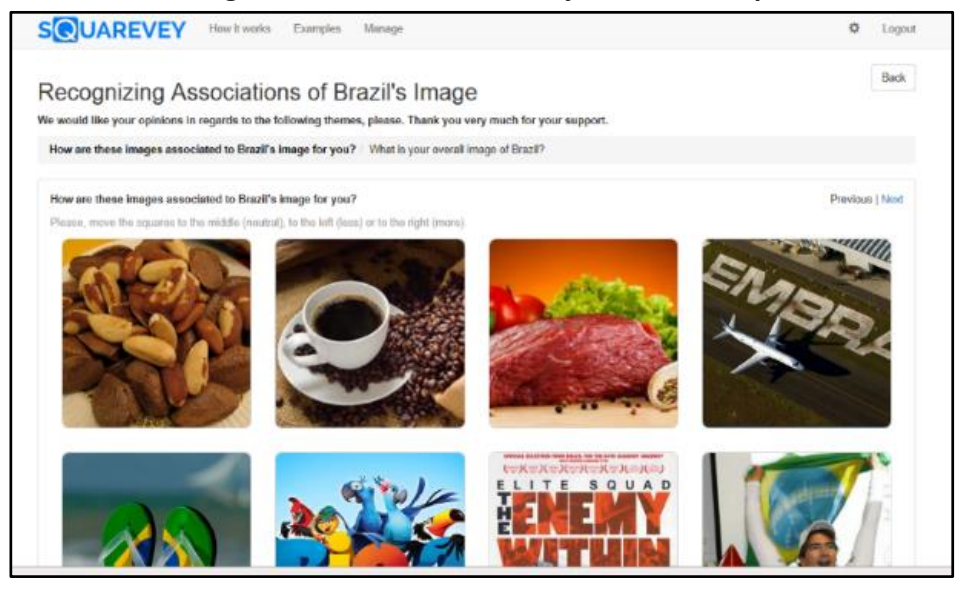

Figure 2 - Photos for Projective Techniques

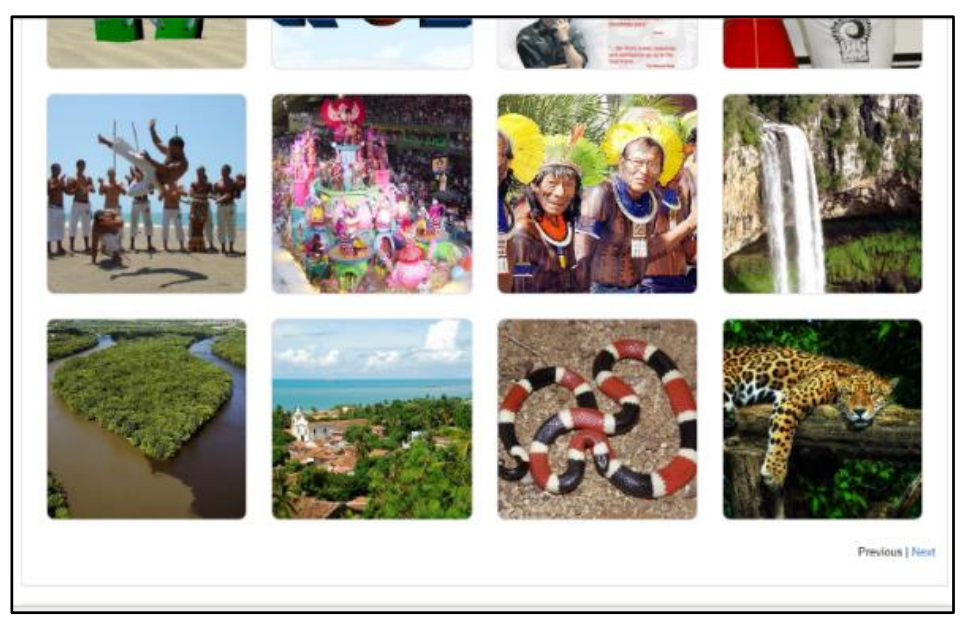


The photographs above were chosen due to their significance to the Brazil's brand identity (APEX-Brasil, 2013; Bignami, 2002; Cinema do Brasil, 2015; Mariutti, 2012; Mariutti \& Giraldi, 2013; Olins, 2013; UNESCO, 2015; WWF, 2015). The descriptions of Illustrations 1 and 2 are below:

\author{
1. Main Brazilian exported products to the UK: \\ 1.1. Brazil nuts \\ 1.2. coffee \\ 1.3. meat \\ 1.4. aircrafts \\ 2. Brazilian style: Flip-flops \\ 3. Main films internationally traded: \\ 3.1. Rio 2 \\ 3.2. Elite Squad
}

4. Sport: Brazilian big-wave surfer champion

5. Sport and culture: martial art dance and music - capoeira

6. Brazilian cultural festival: carnival parade

7. Brazilian native indigenous people

8. Brazilian destinations:

8.1. The waterfall in Rio Grande do Sul State

8.2. The Amazon and Negro rivers in the Amazon, North Region

\subsection{Olinda City in Recife State}

9. Wild animals in Brazil:

9.1. Poisonous coral snake

9.2. Endangered jaguar

For the analysis of the quantitative approach (Creswell, 2014), a descriptive statistics analysis was undertaken. Below, the bar chart (Chart 1) describes the overall analysis to further support the idea of 'flip-flops' as the top association with Brazil (74\%), which can be understood as fashion, a relaxing lifestyle and summertime; this finding directly agrees with Olins' reference (2013). This is followed by the Amazon region (67\%), which could be understood as the geocultural space and a tourist destination of the country. Even though the 'Amazon' was not the most debated concept in Part I, it was the second top theme in the findings for the projective technique. In third place, there was substantial cultural recognition of 'carnival' (65\%), followed by 'Brazil nuts' and 'Brazilian native indigenous people', which were not mentioned in Part I. However, it can be argued that the photographs that achieved less than $49 \%$ recognition are not very representative of an association with Brazil. The whole numerical distribution can be seen below:

\section{Chart 1 - Percentage Distribution of the Photograph Ratings}

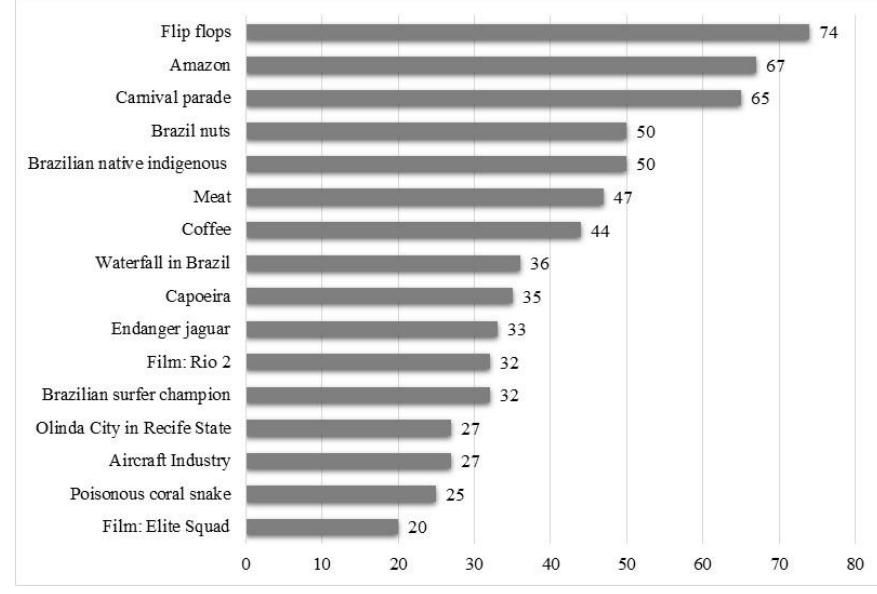

The last question asked in Part II for the participants to answer, using the projective technique, was 'What is your overall image of Brazil?', as seen in Figure 3 below.

Figure 3 - Overall Image of the Country

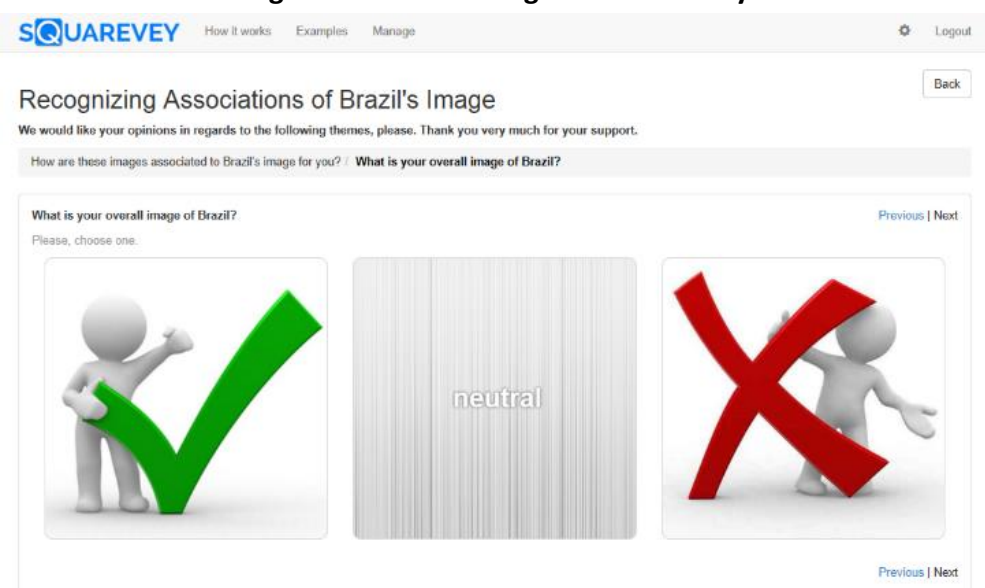


The results of the overall image of the country from the previous Figure 3 indicate that the participants of the focus groups' perceptions of Brazil were $40 \%$ negative and $60 \%$ positive; no one selected a 'neutral' option. Since during the discussion the participants might not have felt comfortable talking straight way about a direct discernment (negative or positive associations with the country), exploring their perceptions was a significant quantitative advantage in the process of collecting data.
Part III - Mentioning Positive and Negative Associations with Brazil

For the final part of the discussion, the participants were asked to specifically write down their top three positive and negative images associated with Brazil, which came to mind when thinking of Brazil. Taken together, these results in Table 1 (below) suggest that there are convergences with the outcomes of Part I and Part II during the focus group discussion.

Table 1 - Findings of Associations with Brazil

\begin{tabular}{|c|c|c|}
\hline Participants & POSITIVE & NEGATIVE \\
\hline [W] & $\begin{array}{l}\text { Growing economy. } \\
\text { Positive culture and resources. } \\
\text { Poverty is decreasing. }\end{array}$ & $\begin{array}{l}\text { Crime. } \\
\text { Political problems. } \\
\text { Education. }\end{array}$ \\
\hline$[\mathrm{X}]$ & $\begin{array}{l}\text { Warm and friendly people and } \\
\text { culture. } \\
\text { Successful football team. } \\
\text { Music. }\end{array}$ & $\begin{array}{l}\text { Poverty (inequality of wealth). } \\
\text { Environmental degradation. } \\
\text { Serious problems with crime (probably linked to poverty). }\end{array}$ \\
\hline$[\mathrm{K}]$ & $\begin{array}{l}\text { Football. } \\
\text { Jazz music. } \\
\text { Food and drink. }\end{array}$ & Crime. \\
\hline [Z] & $\begin{array}{l}\text { Warmth of the people. } \\
\text { Diversity of the people. } \\
\text { Impressive flora and fauna. }\end{array}$ & $\begin{array}{c}\text { Poverty (favelas). } \\
\text { Crime (drug-related). } \\
\text { Corruption ('Tropa de Elite', social inequality and political short-sightedness). }\end{array}$ \\
\hline
\end{tabular}

The outcomes of Part III revealed the richness and diversity of Brazil, as can be seem above. Perhaps, because the simple listing was a free-activity during the meeting, they were more comfortable expressing their anonymous opinions.

By analysing the associations shown, it is possible to determine what types of culture the individuals mentioned when referring to Brazil. For this matter, it is important to explain cultural subsets. The term culture, as explained by Spencer-Oatey $(2012$, p.1), has been used mainly in three different ways: 1 . referring to special intellectual or artistic endeavours or products, contrasting "high culture" with "popular culture". In this sense, a few areas "have culture". 2. In reaction to the previous usage, this refers to culture as a quality possessed by all people in all social groups, which can be arrayed on an evolutionary continuum (from primitive to civilized). In this sense, culture is a "grab bag of things, from knowledge to habits to capabilities" that may be acquired due to membership in some social group (society). 3. The third understanding of culture does not differentiate high from low culture or valorised culture as savage or civilized but emphasizes "the uniqueness of the many and varied cultures of different peoples or societies". Spencer-Oatey criticizes the use of "high" and "low" to describe culture, as culture is a descriptive not an evaluative concept. He proposes that "cultures should be thought of as integrated wholes - that is, cultures are coherent and logical systems, the parts of which to a degree are related" (p.14).

For a better understanding of cultures, some sociologists use cultural subsets to describe subcultures as "high culture" and "popular culture", but this is not a valuation of better or worse (Spencer-Oatey, 2012). High culture is associated with the subculture shared by the elite in a society, while popular culture is the dominant subculture shared by the majority of people in a society (Crossman,2017; Delaney, 2007; Spencer-Oatey, 2012). The elements of popular culture have mass accessibility and appeal, while items of high culture are not mass produced nor meant for mass consumption and often require extensive experience, training, or reflection to be appreciated (Delaney, 2007; Spencer-Oatey, 2012). Delaney (2007) also brings in the definition of folk culture, differentiating it from both high and low culture. For the author, folk culture represents the traditional way of doing things. Although it involves mass participation, it differs from popular culture because it is much more static.

Almost all the associations might be derived from popular culture, except for "jazz music", which is not shared by the majority of people in Brazilian society or disseminated through the mass media.

\section{Final Remarks}

As previously indicated, the aim of this interpretive study was achieved as after a detailed exploration of Brazil's brand image, focusing on 'culture' and its associations as a country brand dimension. In spite of the low number of participants, the data were rich, detailed, and convergent with the reality of Brazil per se. It is important to note that strategies can be planned for the tactical development of place branding and destination branding, i.e., virtual or local campaigns in broadcasting, media planning, and official communications. 
Furthermore, it can be drawn as an unquestionable inference that Brazil's brand consists of several contrasting dimensions, including positive and negative aspects, due to both the changeable scheme of country and the emotional, mental and psychological nature of the association. Furthermore, many areas of everyday cultural experience prove beyond the reach of the globalized market, such as our deeply rooted sense of national or ethnic identities, our religious or spiritual ties, our community interests, activities and attachments, not to mention our environments and social relationships" (UNESCO, 2009, p.14).

The perceived brand of Brazil, based on this sample of British people, is consistent with Anholt (2007) and Dinnie (2009) who note that 'culture' and 'sport' could be well-perceived associations for a country. Recognizing Brazil by its 'diverse and positive culture' as a promising dimension of country brand is recommended by Andéhn and Zenker (2015), Desborde (1990), Fetscherin (2010), Florek and Insch (2008), Zeinalpour, Shahbazi, \& Ezzatirad (2013) and Zenker and Braun (2010). To illustrate this point, as noted by Olins (2013), 'flip-flops' had the top recognition, which indicates a typical cultural fashion accessory in Brazil and an image that is exported worldwide, followed by the 'Amazon', 'Carnival parades' and 'Brazil nuts'. These three associations reinforce the robust cultural references of Brazil's country brand. However, the other images that are less recognized could be more extensively promoted abroad. Certainly, 'sport' and 'football' were often remembered because the World Cup had been held in Brazil the year before this research was conducted and because Brazil has won the most World Cup titles with five trophies in 1958, 1962, 1970, 1994 and 2002 (FIFA, 2016).

Positively, Brazil's brand image is to some extent more favourable than unfavourable based on this sample of English people. Nevertheless, the negative associations were promptly discussed and agree with previous studies (Anholt, 2007; Bignami, 2002; Kotler \& Gertner, 2004; Mariutti \& Giraldi, 2013). Furthermore, the film 'City of God' was mentioned at the beginning of the discussion, as one of the participants says it "shows the reality of the country". The film 'Elite Squad', which was one of the photographs, received the last position behind all the others. Talking about cinema, the film 'Rio 2' had a higher recognition. It is worth noting that during Part I, three participants of the discussion also recalled the film 'Anaconda'. Moreover, all the photographs were somehow recognized, which indicates that they accord with the evidence previously presented (APEX-Brasil, 2013; Bignami, 2002; Cinema do Brasil, 2015; Mariutti, 2012; Mariutti \& Giraldi, 2013; Olins, 2013; UNESCO, 2015; WWF, 2015).

Based on this focus group sample, the news influences their perception of Brazil, as they read and hear about Brazil through media outlets, as England, which is geographically distant from Brazil, does not include the Terra Brasilis among the top destinations for travelling abroad.

Finally, this study can orientate the government, professionals and academics in order to develop country brand campaigns that are reputable, sustainable and successful in order to attract business, investment, and tourism.

The theoretical implications demonstrate that country brand is an endless research domain in which brand identity could be culturally endorsed when promoting a country brand image internationally. Regarding practical implications, one way for countries to enhance their brand associations is to align the cultural dimension with the country brand.

Regarding the limitations of this research, no more than one group participated in the research "given that resources (people, money, time, etc.) were limited" (Flick, 2014, p.177), though the initial proposal for this research included two groups. Moreover, as the low number of participants show, there -a relative lack of interest or time, as the number indicate when compared to the large number of people at the university. In addition, no incentive (e.g., money or gift cards) was offered during the promotion for recruiting the group. However, the limitations of using focus groups as a method are as follows. Few topics can be discussed in one group, and they can produce fewer ideas than interviews (Neuman, 2014); they may not be in-depth enough to provide understanding, and certain personalities may influence the group discussion as well (Liamputtong, 2011). Another limitation is that a focus group provides information in a designated place rather than in people's natural settings (Creswell, 2014), for instance, in Brazilian locations.

Regarding originality and value, this is the first study regarding Brazil's brand image using a focus group of English people as a sample, involving visual methods, and providing the data regarding country brand through a cultural dimension, focusing on country branding and destination branding perspectives.

In conclusion, this research design can be applied to other countries or can create insights for further research in both fields of knowledge. Future studies could be undertaken with other methods (e.g., single interviews and surveys) or in relation to other cultural associations with Brazil's brand image. Another suggestion is to use another country brand dimension for the evaluation, for example, the social and political dimensions. Furthermore, the plethora of associations of a country brand could expand the research in terms of investigating the cultural brands themselves, globally. Finally, another recommendation is to use this methodological framework with a multicultural focus group.

Acknowledgement: CAPES - Coordenação de Aperfeiçoamento de Pessoal de Nível Superior, Brazil, supported this study.

\section{References}

Anholt S., \& Govers, R. (2014). The Good Country. Retrieved August, 15, 2016 from https://goodcountry.org/

Anholt, S. (2007). Competitive Identity: The New Brand Management for Nations, Cities, and Regions. New York: Palgrave Macmillan.

APEX Brasil (2015). Home. Retrieved January, 10, 2016 from http://www.apexbrasil.com.br/home/index 
APEX-Brasil (2016). Discover Brazil. Retrieved January, 10, 2016 http://www.apexbrasil.com.br/en/discover-brazil

Buhmann, A., \& Ingenhoff, D. (2013). Advancing the country image construct from a public relations perspective: the constitution of the country image and its effect on travel behaviour. In EUPRERA 2013 Congress (pp.1-17), Barcelona, Spain.

Caldwell, N., \& Freire, J. (2004). The differences between branding a country, a region and a city: Applying the Brand Box Model. Journal of Brand Management, 12(1), 50-61. DOI: 10.1057/palgrave.bm.2540201.

Carniello, M. F., \& Santaella, L. A. (2012). A imagem turística de São Sebastião (SP). Caderno Virtual de Turismo, 12(3), 287-308.

Castro, R. M., \& Giraldi, J. M. E. (2012). Processo de Desenvolvimento e Gestão de Marca-de-País: Um estudo sobre a Marca Brasil. Revista Turismo Visão e Ação - Eletrônica, 14(2), 164-183. DOI: 10.14210/rtva.v14n2.p164-183.

Creswell, J.W. (2014). Research design: qualitative, quantitative, and mixed methods approaches. Fourth edition, International student edition. Los Angeles: SAGE.

Crossman, A. (2017). Sociological Definition of Popular Culture. Retrieved December, 15, from https://www.thoughtco.com/popular-culture-definition-3026453

Delaney, T. (2007). Pop Culture: An Overview. Philosophy Now, 64 (nov/dec). Retrieved December, 13, 2017 from https://philosophynow.org/issues/64/Pop_Culture_An_Overview

Dinnie, K. (2009). Nation Branding: Concepts, Issues, Practice. Oxford: Elsevier.

Dinnie, K. (2016). Nation Branding: Concepts, Issues, Practice. $2^{\text {nd }}$ Edition. Oxon: Routledge.

Embratur (2016). Chegadas Internationais. Retrieved December, 01, 2016 from http://basededados.turismo.gov.br/

Fetscherin, M. (2010). The determinants and measurement of a country brand: the country brand strength index. International Marketing Review, 27(4), 466-479. DOI: 10.1108/02651331011058617

FIFA (2016). FIFA World Cup. Retrieved December, 22, 2016 http://www.fifa.com/search/index.html?q=Brazil\%20

Flick, U. (2014). An Introduction to Qualitative Research. $5^{\text {th }}$ ed. London: Sage.

Florek, M., \& Insch, A. (2008). The trademark protection of country brands: Insights from New Zealand. Journal of Place Management and Development, 1(3), 292-306. DOI: 10.1108/17538330810911271

Giraldi, J. M. E.; Giraldi, I., M.E.; Scaduto, A. A. (2011). Brazil's image as a social representation process. African Journal of Business Management, 5(22), 8821-8831. DOI: 10.5897/AJBM10.1510

Gomes, M. S. (2012). A Imagem do Brasil no Exterior e o Turismo: A Operacionalização do Plano Aquarela em Portugal. Rosa dos Ventos, 4(4), 506-521.

Hair, J., Wolfinbarger, M., Ortinau, D.J., \& Bush, R.P. (2010). Essentials of Marketing Research. Boston: McGrawHill.

Kajihara, K. (2010). A imagem do Brasil no exterior: Análise do material de divulgação oficial da EMBRATUR, desde 1966 até 2008. Observatório de Inovação do Turismo, 5(3), 1-30.

Kotler, P., \& Gertner, D. (2002). Country as brand, products, and beyond: A place marketing and brand management perspective. Journal of Brand Management, 9(4/5), 249-261. DOI: 10.1057/palgrave.bm.2540076

Kotler, P., \& Keller, K. L. (2012). Marketing Management. $12^{\text {nd }}$ ed. New Jersey: Pearson Prentice-Hall.

Kotler, P., Haider, D., \& Rein, I. (1993). Marketing Places: Attracting Investment, Industry, and Tourism to Cities, States, and Nations. New York: The Free Press.
Liamputtong, P. (2011). Focus Group Methodology: Principles and Practice. London: Sage.

Maheshwari, V., Vandewalle, I., \& Bamber, D. (2011). Place branding's role in sustainable development. Journal of Place Management and Development, 4(2), 198-213. DOI: 10.1108/17538331111153188

Mariutti, F. G., \& Giraldi, J. M. E. (2013). Country Brand Identity: Communication of the Brazil Brand in the United States of America. Saarbrucken: LAP Lambert Academic Publishing.

Mariutti, F. G., \& Silverio, A. (2016). How well do you know Brazil's dances? An Analysis into the Cultural Dimension of a Country Brand. In $\checkmark$ Oxbridge Conference on Brazilian Studies. Oxford, England.

Mariutti, F. G., \& Tench, R. (2016). How does Brazil measure up? Comparing rankings through the lenses of nation brand indexes. Place Branding and Public Diplomacy, 12, 17-31. DOI: 10.1057/pb.2015.19

Martín-Santana, J. D., Beerli-Palacio, A., \& Nazzareno, P. A. (2017). Antecedents and consequences of destination image gap. Annals of Tourism Research, 62, 13-25. DOI: 10.1016/j.annals.2016.11.001

Neuman, W. L. (2014). Social research methods: qualitative and quantitative approaches. $7^{\text {th }}$ ed. Essex: Pearson.

O'Neil, I. (2007). British Travellers' image perspectives of Brazil as a tourism destination. Observatório de Inovação do Turismo Revista Acadêmica, I(4), 1-22. DOI: 10.12660/oit.v1n4.5628

Olins, W. (2013). Nation Branding. Cl-Convention on Nation Branding, in Graz [video]. Retrieved March, 10, 2014 from https://www.youtube.com/watch?v=Bc-N1Upvgr8andapp=desktop

Pike, S. D. (2008). Destination Marketing: an integrated marketing communication approach. Oxford: Elsevier.

Ribeiro, D. (1995). O Povo Brasileiro. $2^{\text {nd }}$ ed. São Paulo: Companhia das Letras.

Rohter, L. (2012). Brazil on the Rise: The Story of a Country Transformed. New York: Palgrave.

Rojas-Méndez, J. (2013). The Nation Brand Molecule. Journal of Product and Brand Management, 22(7), 462-472. DOI: 10.1108/JPBM-09-20130385

Spencer-Oatey, H. (2012). What is culture? A compilation of quotations. GlobalPAD Core Concepts. Retrieved December, 10, 2017 from http://www.warwick.ac.uk/globalpadintercultural

UKTI (2016). UK and Brazil. Retrieved September, 18, 2017 from https://www.gov.uk/government/world/organisations/uk-tradeinvestment-brazil

UNESCO (2009). Investing in Cultural Diversity and Intercultural Dialogue. Paris: United Nations Educational, Cultural and Scientific Organization.

UNESCO (2015). Brazil. Retrieved October, 12, 2016 from http://whc.unesco.org/en/statesparties/BR/

WWF (2015). Brazil. Retrieved October, 12, 2016 from http://www.worldwildlife.org/places/amazon

Zeinalpour, H., Shahbazi, N., \& Ezzatirad, H. (2013). A Review on City and Country Brand Index. World Applied Sciences Journal, 27(11), 14011407. DOI: 10.5829/idosi.wasj.2013.27.11.829.

Zenker, S., \& Braun, E. (2010). Branding a city - a conceptual approach for place branding and place brand management. In: $39^{\text {th }}$ European Marketing Academy Conference, Copenhagen, Denmark.

Zenker, S., Peterson, C., \& Anholt, S. (2013). The Citizen Satisfaction Index (CSI): Evidence for a Four Basic Factor Model in a German Sample. Cities, 31(4), 156-164. DOI: 10.1016/j.cities.2012.02.006

Received: 19 January 2017

Revisions required: 25 September 2017

Accepted: 28 November 2017 